\title{
ANTIOXIDANT, TOXICITY AND ANTIBACTERIAL PROPERTIES OF Ompu-ompu (Crinum asiaticum-L) ETHANOL EXTRACT
}

\author{
Ida Duma Riris ${ }^{1}{ }^{*}$, Murniaty Simorangkir ${ }^{1}$ and Albinus Silalahi ${ }^{1}$ \\ ${ }^{1}$ Chemistry Education Department, State University of Medan, North Sumatra, Indonesia. \\ *E-mail:dumariris@gmail.com
}

\begin{abstract}
The Crinum plant varieties found, called "Oтри-ompu", identified as a type of Crinum asiaticum- $L$ which used as a drug. The antioxidant, toxicity and antibacterial of the Crinum leaves and bulbs extracted with ethanol and treated by DPPH (2-2 diphenyl 1-1-picrylhydrazyl) method, Brine Shrimp Lethality Test (BSLT) method, and diffusion method respectively. It was found that both the leaves and bulbs have an antioxidant site with $54.21 \mathrm{ppm}$ and $33.79 \mathrm{ppm}$ respectively through $\mathrm{IC}_{50}$ test $25.8 \mathrm{ppm}$ which used vit.C as a control. Furthermore, it was found that their toxicity measured by $\mathrm{LD}_{50}$ is 243.331 and 507.838 respectively. In addition, the antibacterial test showed that the widest inhibition of the leaves and bulbs are $15.7 \mathrm{~mm}$ and $12.4 \mathrm{~mm}$ against Escherichia coli respectively and $12.3 \mathrm{~mm}$ and $11.5 \mathrm{~mm}$ against Staphylococcus aureus. Phytochemical screening indicated the presence of alkaloids, flavonoid, saponins and tannins.
\end{abstract}

Keyword: antibacterial, antioxidant, Crinum Asiaticum L, toxicity, phytochemical

@) RASĀYAN. All rights reserved

\section{INTRODUCTION}

The Crinum is a flowering plant, which is one of the large genus in the Amaryllidaceae family. There are 180 species of this plant, which are spread out in Asia, Australia, Africa and America, which have secondary metabolite content especially alkaloids ${ }^{1}$. It is typically white to pink and grows in tropical and sub-tropical regions. One type of the plant is found in Haunatas Village, Tobasa District, North Sumatra Indonesia, with typically white and its height reaches one and a half meters. Local people call it "Oтри-Oтри" as shown in Fig.-1.

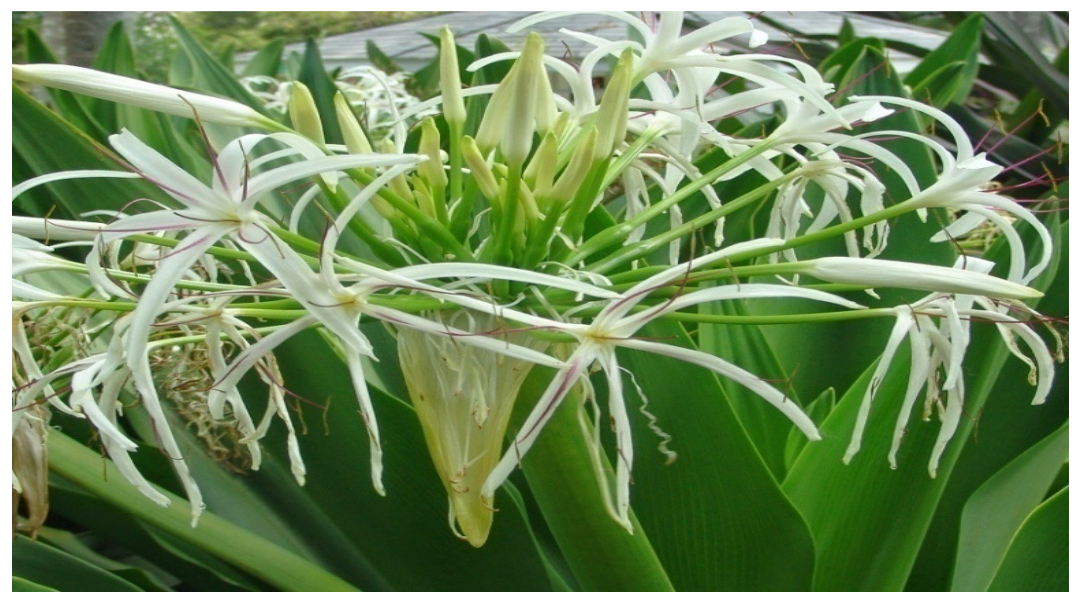

Fig.-1: “Ompu-ompu”- Crinum asiaticum L.

The plant is classified into a Crinum asiaticum- $L$ species of Genus Amaryllidaceae family based on the family identification, which identified in Pharmacy laboratory of North Sumatra University. Generally, the local community uses it as a medicine.

Rasayan J. Chem., 11(3), 1229-1235(2018)

http://dx.doi.org/10.31788/RJC.2018.1133090 
The leaves have a function to overcome the swelling of the human body due to impact or sprains. It is carried out by applying oil on to the leaves, and then heat and place it on the swollen parts. Phyto screening results of bulbs of Crinum asiaticum L. var. sinicum BAKER from China has found 21 compounds that have activity as anti-tumor ${ }^{2}$.

The investigation of Crinum aurebensaiton through alkaloid isolation process ${ }^{3}$ revealed that it contains dehidro anhidroclorine. Likewise, research on the Crinum jagus and Crinum glaussum species found that alkaloids from extracts of bulbs showed inhibition of acetyl colinesferase, and it results in the depressed levels of acetylcholine in the brain associated with Alzheimer's disease ${ }^{4}$. It reported that the alkaloid compounds have protective properties due to the presence of lycorine compounds in the leaves which are considered as an important source of natural antioxidants ${ }^{5,6}$.

It has been identified that Crinum species contains 118 different alkaloids ${ }^{7}$ which was determined through Phytochemical test ${ }^{8}$. The alkaloids are generally beneficial to human health such as in weight loss program, antinociception, antihitperalgesic, sedative, and antioxidant. Furthermore, it can reduce the blood sugar levels or it can be used as an antidiabetic agent ${ }^{9,10}$. In other sources, also reported that it can be used as an anti-tumor, immunostimulan, analgesic, and anti-bacterial ${ }^{11}$. It is considered as an antioxidant because it is not only can stabilize free radicals but also can inhibit the formation of the free radicals which cause oxidative stress $^{12,13}$. As previous researchers tested the antioxidant by dpph method at $517 \mathrm{~nm}^{14-17}$, in this study for antioxidants performed with a spectrophotometer with $517 \mathrm{~nm}$.

The antioxidants can be found in several types of plants, and it reported that those derived from plants are better than synthetic antioxidants, because the synthetic one can negatively affect human health when consumed $^{18}$. The other important point of concerns in utilizing the plant which is toxic properties. The toxicity of a plant is considered as an indication of the potential of compounds as a medicinal plant (bioactivity) ${ }^{19,20}$. There are 7 types of alkaloids from cognates with Crinum that have significant toxicity and activity against antibacterial and cancer resistance ${ }^{21}$ which were tested by the Brine Shrimp Lethality Test (BSLT) $)^{22}$.

The investigation of the existing Crinum plant at various sites expands the crop inventory because the production of an organic compound secondary metabolite of a plant is closely related to environmental factors where it grows ${ }^{23}$. Investigation results of the Crinum from the Haunatas Village showed that the antioxidant, toxicity, and antibacterial of the plant are highly valuable and presented in detail in this paper.

\section{Collection of Plant}

\section{EXPERIMENTAL}

Crinum asiaticum L is obtained from the peasant Haunatas Village North Sumatera Indonesia.

\section{Preparation of Plant Extract}

A total of $15 \mathrm{~kg}$ freshly Crinum asiaticum- $L$ has separated the leaves and bulbs, and then washed with 500 $\mathrm{ml}$ of distilled water and sliced with a knife. Before drying, the blanching process was done by boiling for 5 minutes used $0,5 \%$ citric acid at temperature $100^{\circ} \mathrm{C}^{24}$, air dried at room temperature for 14 days. The dried leaves and bulbs blendered mashed to get the powder extract. The next, 500 gr of leaves and bulbs powder were macerated with 2 liters of ethanol solvent for $3 \times 24$ hours. The same process was carried out 3 times then the results were filtered with Buchner. The filtrate was concentrated by vacuum rotary evaporator until the ethanol extract is collected. Further bioactivity measurement was carried out by phytochemicals, antioxidants, toxicity, and antibacterial tests.

\section{Phytochemical Screening}

The Chemical screening of Ethanol extract plant was found by the Harborne method, $1987^{8}$.

\section{Antioxidant Assay}

The DPPH (2-2 diphenyl 1-1- picrylhydrazy) method is used for the antioxidant test by making ascorbat acid with concentration 5, 10, 25, 50, dan 100 ppm as a control. Furthermore, DPPH powder is dissolved in methanol p.a and made a comparative test solution of $2 \mathrm{~mL}$ inserted into the test tube by adding the solution of $2 \mathrm{~mL}$ DPPH $0.1 \mathrm{mM}$, and stirred with vortex until homogeneous. The homogeneous solutions 
RASĀYAN J. Chem.

Vol. 11 | No. 3 |1229 - 1235 | July - September | 2018

were incubated in the dark for 30 minutes, and measured uptake at a $517 \mathrm{~nm}$ using the visible spectrophotometer. Based on this, the percentage of inhibition is calculated by the formula,

Activity $(\%)=[(\mathrm{A}-\mathrm{B}) / \mathrm{A}] \mathrm{X} 100 \%$

Where, A is the absorbance of control (DPPH solution without the sample), B is the absorbance of the DPPH solution in the presence of the sample (extract/ ascorbic acid) ${ }^{25}$.

The Inhibition Concetration 50( $\left.\mathrm{IC}_{50}\right)$ value is the concentration of antioxidants $(\mathrm{ppm})$ which is able to inhibit $50 \%$ of the free radicals, whose value is indicated by the intersection of the intermediate line of 50\% inhibition power with the concentration axis, then incorporated into the equation,

$\mathrm{Y}=\mathrm{a}+\mathrm{bX}$

Where $\mathrm{Y}=50$, and the $\mathrm{X}$ value showed $\mathrm{IC}_{50}$.

\section{Toxicity Test}

The toxicity test used Brine Shrimp Lethality Test (BSLT). The fifteen vials were prepared with five different concentrations of test solution such as 1000, 500,200,100, $10 \mathrm{ppm}$. The analysis was done for three-time replication include the control. The main solution was prepared by dissolving $0.2 \mathrm{~g}$ of extract into seawater extract until $100 \mathrm{ml}$ of volumetric flask and homogenized. The main solution was taken 2500 , $1250,500,250,25 \mathrm{ppm}$ respectively to make a solution with concentrations of 1000, 500, 200, 100, 10 $\mathrm{ppm}$. The solution was stirred until homogeneous and evaporated until dry. Each concentration was made in 3 vials, then into each vial inserted $5 \mathrm{ml}$ of seawater and 10 naupli for 2 hours then observed the number of death shrimp larvae with a magnifying glass.

Furthermore, the $\mathrm{LC}_{50}$ was calculated with the concentration of test substance that can kill shrimp larvae as much as $50 \%$ with SPSS 20 application. In this case, the sample was very toxic to shrimp larvae Artemiasalina Leach if the value of $\mathrm{LC}_{50}<30 \mu \mathrm{g} / \mathrm{ml}$, toxic if $30 \mu \mathrm{g} / \mathrm{ml} \geq \mathrm{LC} 50 \leq 1000 \mu \mathrm{g} / \mathrm{ml}$, and not toxic when $\mathrm{LC}_{50}>1000 \mu \mathrm{g} / \mathrm{ml}^{26}$.

\section{Antibacterial Screening}

Instruments sterilization were important before test analysis. Glasses were sterilized in the oven with $100^{\circ} \mathrm{C}$ for 2 hours. On the other hand, metals were sterilized with a spray-mounted light, and for heat-resistant appliances and the high-temperature medium was sterilized in an autoclave at $121 \mathrm{oC}, 2 \mathrm{~atm}$ for 15 minutes. $2.3 \mathrm{~g}$ of NA (Nutrient Agar) were added and mixed with $100 \mathrm{~mL}$ aquabidest in the beaker glass until homogenous. This homogenous mixture was autoclaved for sterilization. The UV light was ignited on the laminary for 15 minutes and blown for 10 minutes, then poured into the petri dish as a medium.

Escherichia coli as a sample were reconstructed before being used for antibacterial tests. The bacteria were cultured on a bend sterilized agar, then incubated for 24 hours at $37^{\circ} \mathrm{C}$. The Bacterial suspension was spread using a sterile cotton swab on nutrient agar plat. The turbidity of each bacterial culture was adjusted to $0,5 \mathrm{McF}$ arland Standard then incubated for 24 hours $^{27,28}$. The ethanol extract was dissolved in concentrations of $0 \%, 2.5 \%$, and $5 \%$.. Chloramphenicol $0.02 \%$ were used as reference drug for bacteria (as much as 0.002 grams of chloramphenicol dissolved in $10 \mathrm{~mL}$ of distilled water $(0.025)(\mathrm{w} / \mathrm{v})^{29}$. Zone of Inhibition was measured in $\mathrm{mL}$.

\section{RESULTS AND DISCUSSION}

Based on the fitoscreening test of the leaves and bulbs ethanol extract (Table-1). It was found that the leaves contain an alkaloid, flavonoid, saponin, and tannin, as well as in the bulbs except for tannin. This suggests that the "Отри-отри" may have a variety of bioactivity such as antibacterial, antioxidant, toxicity, anticancer and others ${ }^{30-31}$.

The antioxidant test for the ethanol extract is used with the DPPH method which used UV-Vis at $517 \mathrm{~nm}$. The result showed that the leaves and bulb shave the antioxidant value of $54.21 \mathrm{ppm}$ and $33.79 \mathrm{ppm}$ respectively with the $25.8 \mathrm{ppm}$ of vit. $\mathrm{C}$ as the control solution (Table-2). These indicated that the "Ompuотри" has antioxidant properties, which presented in Fig.-2. This is similar to the antioxidant activity of methanol extracts of crops found in Bangladesh which were measured by DPPH (1,1-diphenyl-2picrylhydrazyl) method, with the vitamin $\mathrm{C}$ as a control ${ }^{12}$ and also found at the Cauvery river basin, Thanjavur, Tamilnadu India ${ }^{7}$. Isolation and identification results showed the phenolic compounds as the 


\section{RASĀYAN J. Chem.}

Vol. 11 | No. 3 |1229 - 1235 | July - September | 2018

previous research ${ }^{33}$. This phenolic concentration indicates the presence of antioxidant activity ${ }^{34}$.The toxicity of the crinum leaves and bulbs ethanol extracts graphically shown in Table-3 and Fig.-3.

Table-1: Phytochemicals of Crinum asiaticum L Ethanol Extract of Bulbs and Leaves

\begin{tabular}{c|c|c|c}
\hline No. & Phytochemicals & Leaves & Bulbs \\
\hline 1. & Alcaloid & + & + \\
\hline 2. & Flavonoid & + & + \\
\hline 3. & Saponin & + & + \\
\hline 4. & Tanin & + & - \\
\hline
\end{tabular}

The death of naupli in hour difference is seen on the vertical axis, and the leaves and bulbs extract concentration $(\mu \mathrm{g} / \mathrm{mL})$ is visible on the horizontal axis. By using the SPSS version 22, It was found that the $\mathrm{LC}_{50}$ value of the leaves and bulbs are $243,331 \mathrm{ppm}$ and 507,838 ppm respectively. It shows that both the leaves and the bulbs are showing toxic properties. The result is in line with the previous research ${ }^{19}$ which shows that the toxic properties of a substance are known if the value of $\mathrm{LC}_{50}$ is $<1000 \mathrm{ppm}$ for the extract and $\leq 30 \mathrm{ppm}$ for a compound. It is presumed that the "Oтри-отрu" is considered as a potential and promising medicinal plant. Because the plants have toxic properties ${ }^{18,23}$ which are similar to the toxicity of the 7 alkaloids found in Licorisaurea(Amaryllidaceae) that have a significant antibacterial activity and even potentially as an anticancer ${ }^{20}$.

Table-2: Antioxidant of Crinum asiaticum L Ethanol Extract

\begin{tabular}{|c|c|c|c|c|}
\hline Extract & Concentration (ppm) & Absorbance & $\%$ Resistance & $\mathrm{IC}_{50}(\mathrm{ppm})$ \\
\hline \multirow{5}{*}{ Bulbs } & 5 & 0.233 & 57.48 & \\
\hline & 10 & 0.2271 & 58.55 & \\
\hline & 25 & 0.1666 & 69.59 & \\
\hline & 50 & 0.1382 & 74.78 & 33.79 \\
\hline & 100 & 0.095 & 82.26 & \\
\hline \multirow{5}{*}{ Leaves } & 5 & 0.2496 & 54.45 & \\
\hline & 10 & 0.1805 & 67.06 & \\
\hline & 25 & 0.1125 & 79.47 & \\
\hline & 50 & 0.092 & 83.21 & 54.21 \\
\hline & 100 & 0.0824 & 84.96 & \\
\hline \multirow{5}{*}{ Vitamin C } & 5 & 0.3209 & 41.44 & \\
\hline & 10 & 0.1693 & 69.11 & \\
\hline & 25 & 0.1406 & 74.34 & \\
\hline & 50 & 0.1243 & 77.32 & 25.08 \\
\hline & 100 & 0.0912 & 83.36 & \\
\hline
\end{tabular}

The antibacterial agent of the leaves and bulbs ethanol extracts at various concentrations of 2.5\% and 5\% was indicated by its resistance diameters against Escherichia coli and Staphylococcus aureus (Table-4). The extent of inhibition obtained for the Escherichia coli bacteria was 12.4 (the leaves) and 15.7 (the bulbs); and the Staphylococcus aureus with an area of 11.5 (the leaves) and 12.3 (the bulbs). 
RASĀYAN J. Chem.

Vol. 11 | No. 3 |1229 - 1235 | July - September | 2018

Tabel-3: Toxicity of the "Oтри-отри" - Crinum asiaticum L Leaves and Bulbs Ethanol Extract

\begin{tabular}{c|c|c|c|c|c}
\hline Extract ethanol & Concentration $(\mathrm{ppm})$ & Mortality & \% Lethality & Total (n) & LC $_{50}(\mathrm{ppm})$ \\
\hline \multirow{4}{*}{ Bulbs } & 10 & 2 & 20 & 10 & 154.546 \\
\cline { 2 - 6 } & 100 & 5 & 50 & 10 & 243.349 \\
\cline { 2 - 6 } & 200 & 7 & 70 & 10 & 300.169 \\
\cline { 2 - 6 } & 500 & 9 & 90 & 10 & 507.838 \\
\hline \multirow{5}{*}{ Leaves } & 1000 & 3 & 100 & 10 & Infinity \\
\cline { 2 - 6 } & 10 & 4 & 40 & 10 & 52.435 \\
\cline { 2 - 6 } & 200 & 6 & 60 & 10 & 130.495 \\
\cline { 2 - 6 } & 500 & 10 & 100 & 10 & 243.331 \\
\cline { 2 - 6 } & 1000 & & & 10 & 29985.832 \\
\hline
\end{tabular}

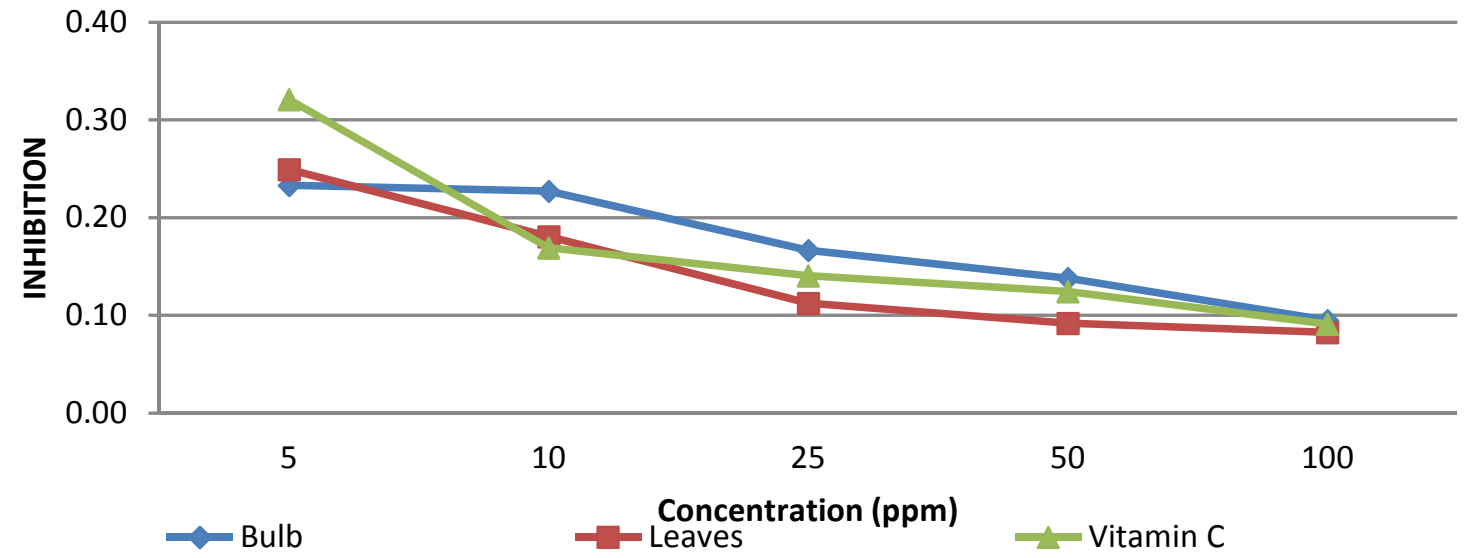

Fig.-2: Antioxidant of Crinum asiaticum L Extract Graph

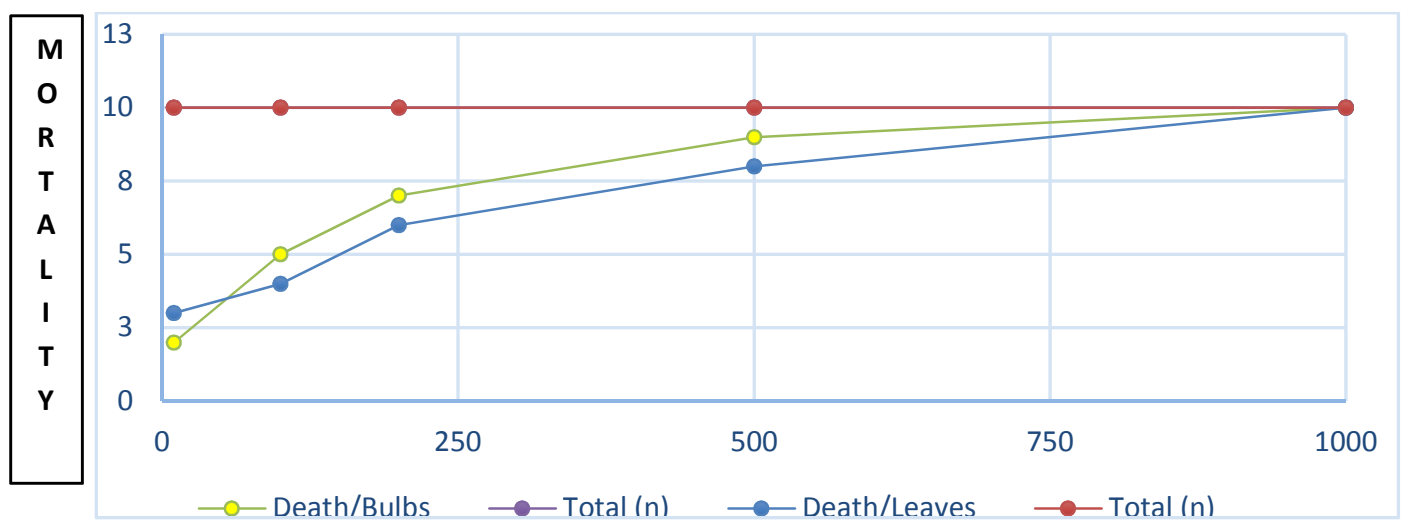

\section{CONCENTRATION (ppm)}

Fig.-3: Toxicity Graph of Crinum asiaticum L' Bulbs and Leaves 


\section{RASĀYAN J. Chem.}

Vol. 11 | No. 3 |1229 - 1235 | July - September | 2018

The inhibition power of the bulbs ethanol extract is greater than the leaves ethanol extracts against both bacteria. And when compared to the chloramphenicol controlled compound, the resistance power of the leaves and bulbs ethanol extract to the Escherichia coli was 34.73-49.06\%; and for the staphylococcus aureus was $35.04 \%$ - 49.56\%. It means that the antibacterial power of the Crinum found as strong as the previous findings ${ }^{29}$, such as the antibacterial species of Boophone disticha (Amaryllidaceae), which has been processed and used as a traditional medicines ${ }^{22}$.

Table-4: The Antibacterial activity of C.asiaticum L Bulb and Leaves of Extract Ethanol

\begin{tabular}{|c|c|c|c|c|c|}
\hline \multirow{4}{*}{$\begin{array}{l}\text { Extract Ethanol } \\
\text { of Plant }\end{array}$} & \multirow{4}{*}{ Bacteria } & An & acteria & & \multirow{4}{*}{$\begin{array}{c}\text { Cloramphenico } \\
(0,02 \%)\end{array}$} \\
\hline & & \multicolumn{3}{|c|}{ The diameter of the zone of inhibition (mm) } & \\
\hline & & \multicolumn{3}{|c|}{ The concentration of Extract (\%) } & \\
\hline & & 0 & 2,5 & 5 & \\
\hline \multirow{2}{*}{ Bulbs } & Escherichia coli & 0 & 11,8 & 15,7 & 32,7 \\
\hline & $\begin{array}{c}\text { Staphylococcus } \\
\text { aureus }\end{array}$ & 0 & 7,1 & 12,3 & 35,1 \\
\hline \multirow[b]{2}{*}{ Leaves } & Escherichia coli & 0 & 8,2 & 12,4 & 35,7 \\
\hline & $\begin{array}{c}\text { Staphylococcus } \\
\text { aureus }\end{array}$ & 0 & 6,8 & 11,5 & 23,2 \\
\hline
\end{tabular}

\section{CONCLUSION}

It is concluded, that the "Oтри-отри”- Crinum asiaticum-L which located in the Haunatas Village contains alkaloid compounds which have strong antioxidant, toxicity, and antibacterial properties. It is highly recommended that the crinum plant is considered as a potential herbal medicinal plant and endorsed to carry out in detail research to trace other potential activities.

\section{ACKNOWLEDGMENT}

I would like to thank the State University of Medan, who funded this research with a contract No. 206 A/UN 33.8/PL/2017

\section{REFERENCES}

1. J. R. Lewis, ChemInform., 33(26), (2010), DOI: 10.1002/chin.200226247

2. Q. Sun, Y. -H. Shen, J. -M. Tian, J. Tang, J. Su, R. -H. Liu, W. D. Zhang, Chemistry and Biodiversity, 6(10), 1751(2009), DOI:10.1002/cbdv.200800273

3. C. G. Guerrieri, N. B. Pigni, J. P. de Andrade, V. D. dos Santos, F. Binns, W. de Souza Borges, J. Bastida, Arabian Journal of Chemistry., 9(5), 688(2016), DOI:10.1016/j.arabjc.2015.07.009

4. P. J. Houghton, J. M. Agbedahunsi and A. Adegbulugbe, Phytochemistry., 65(21), 2893(2004), DOI:10.1016/j.phytochem.2004.08.052

5. S. Ilavenil, B. Kaleeswaran, P. Sumitha, D. Tamilvendan and S. Ravikumar, Saudi., Journal of Biological Sciences., 18(2), 181(2011), DOI:10.1016/j.sjbs.2010.11.001

6. P. Cao, D. -S. Pan, S. Han, C. -Y. Yu, Q. -J. Zhao, Y. Song and Y. Liang, Archives of Pharmacal Research., 36(8), 927(2013), DOI:10.1007/s12272-013-0089-3

7. N. Thi Ngoc Tram, T. Titorenkova, V. St. Bankova, N. Handjieva and S. Popov, Fitoterapia, 73(3), 183(2002), DOI:10.1016/s0367-326x(02)00068-0

8. J. B. Harborne, Phytochemical Methods, Chapman \& Hall London International Diabetes Federation, Atlas Sixth Ed., 2013 (www idf.org/diabetesatlas).

9. Y. J. Jeong, E. -H. Sohn, Y. -H. Jung, W. -J. Yoon, Y. M. Cho, I. Kim, S. C. Kang, Biomedicine \& Pharmacotherapy., 82, 35(2016), DOI:10.1016/j.biopha.2016.04.067

10. W. D. Ratnasooriya, S. A. Deraniyagala, S. D. N. K. Bathige and H. D. I. Hettiarachchi, Journal of Ethnopharmacology., 97(1), 123(2005), DOI:10.1016/j.jep.2004.10.024 
RASĀYAN J. Chem.

Vol. 11 | No. 3 |1229 - 1235 | July - September | 2018

11. M. A. Rahman, R. Sharmin, M. N. Uddin, M. S. Rana and N. U. Ahmed, Bangladesh Journal of Microbiology., 28(1), (2012), DOI:10.3329/bjm.v28i1.11801

12. TOPIC 07- Oxydative stress and aging. Archives of Cardiovascular Diseases Supplements., 4, 18(2012), DOI:10.1016/s1878-6480(12)70793-0

13. V. Lobo, A. Patil, A. Phatak and N. Chandra, Pharmacognosy Reviews., 4(8), 118(2010), DOI:10.4103/0973-7847.70902

14. J. Srivastava, D. Desh, P. Poonam, Rasayan Journal Chemistry., 8(2), 161(2015).

15. J. A. O. Olugbuyiro, S. B. Anuoluwapo, O. A. Alaba, S. T. Olugbenga, A. Oyeronke, Rasayan Journal Chemistry.,11(2), 798(2018), DOI:10.31788/rjc.2018.1121823

16. Y. Taufik, W. Tantan, G. Yudi, Rasayan Journal Chemistry., 9(4), 762(2016).

17. S. L. Deore, S. S. Khadabadi, S. P. D. Patel, M. S. Jaju, N. R. Junghare, T. P. Wane, R. G. Jain, Rasayan Journal Chemistry., 2(1), 129 (2009).

18. S. Azam, M. Mahmud, M. Naquib, S. Hossain, M. Alam, M. Uddin, M. Hasan, ,Biomedicines., 4(3), 17(2016), DOI:10.3390/biomedicines4030017

19. T. J. Kim, J. L. Silva, M. K. Kim and Y. S. Jung, Food Chemistry., 118(3), 740(2010), DOI:10.1016/j.foodchem.2009.05.060

20. A. Azhari, Scientiae Educatia., 3(2), (2014), DOI:10.24235/sc.edu.v3i2.539

21. J. -H Song, L. Zhang, L. Y. Song, Fitoterapia., 95, 121(2014), DOI:10.1016/j.fitote.2014.03.006

22. B. Meyer, N. Ferrigni, J. Putnam, L. Jacobsen, D. Nichols and J. McLaughlin., Planta Medica., 45(5), 31(1982), DOI:10.1055/s-2007-971236

23. T. M. Kutchan, Plant Physiology., 125(1), 158(2001), DOI:10.1104/pp.125.1.58

24. I. Doymaz, Food and Bioproduct Processing., 88(2-3), 124(2010), DOI:10.1016/j.fbp.2009.09.003

25. M. A. Rahman, R. Sharmin, M. N. Uddin, M. S. Rana and Ahmed., Bangladesh Journal of Microbiology., 28(1), (2012), DOI:10.3329/bjm.v28i1.11801

26. M. Steven and Russell Molyneux., CRC Press Boca Raton Ann Arbor London Tokyo. (1985)

27. A. Zapata and S. Ramirez-Arcos, Current Microbiology., 70(6), 907(2015), DOI:10.1007/s00284015-0801-2

28. J. H. Wicks, R. L. Nelson and G. E. Krejcarek, Journal of Clinical Microbiology, 17(6), (1983)

29. M. Steven and R. Molyneux, Bioactive Natural Products. CRC Press,Tokyo, 3-14 (1993).

30. D. W. Lambe and W. Wayne Laslie, Anaerobic Bacteria., 51-60,(1980), DOI:10.1007/978-1-46133159-9_6

31. S. A. Adesanya, T.A. Olugbade, O. O. Odebiyl and J. A. Aladesanmi, Pharmaceutical Biology., 30(4), 303(1992), DOI:10.3109/13880209209054019

32. L. Cheesman, J. J. Nair and J. Van Staden, Journal of Ethnopharmacology., 140(2), 405(2012), DOI:10.1016/j.jep.2012.01.037

33. M. S. Blois, Nature., 18, 4617(1958), DOI:10.1038/1811199a0

34. Q. Sun, W. D. Zhang, Y. H. Shen, C. Zhang and H. L. Li, Chinese Chemical Letters., 19(4),447(2008), DOI:10.1016/j.cclet.2008.01.022

35. C. N. Kunyanga, J.K. Imungi, M. W. Okoth, H. K. Biesalski and V. Vadivel, LWT - Food Science and Technology., 45(2), 269(2012), DOI:10.1016/j.lwt.2011.08.006

[RJC-3090/2018] 